\title{
Analysis of the level of knowledge of mothers about self-medication to children in Cangkringan District, Yogyakarta
}

\section{Analisis tingkat pengetahuan para ibu tentang swamedikasi pada anak di Kecamatan Cangkringan Yogyakarta}

\author{
Yosi Febrianti*1, Dessy Milanitaํㅜ, Bondan Ardiningtyas ${ }^{2}$ \\ 1Jurusan Farmasi, FMIPA, Universitas Islam Indonesia \\ ${ }^{2}$ Fakultas Farmasi, Universitas Gadjah Mada \\ *Corresponding author: yosi.febrianti@uii.ac.id
}

\begin{abstract}
Background: Self-medication refers to an endeavor that is mostly frequently done by society in coping with any symptoms of disease prior to have an aid from medical practitioner. In this case, knowledge about medication and any disease complaints will bring about the impact on the medication use. Insufficiency of mother in understanding about drug and the way of using it in selfmedication is potential to be a factor of medication error both for the mothers themselves and for their family. Knowledge required to properly do self-medication is by identifying the active substances, indication, contraindication, dosage and side effect of the medication.

Objective: This research is designed to observed the description of the implementation of selfmedication, the description of knowledge level of mothers about self-medication and factors determining the knowledge level of mothers.

Method: In addition, this research used questionnaires written in accordance with the Guidelines of Free Medicine Use and Limited Free Medicine. Categorization of the knowledge level of mothers is based on the final score of the questionnaires.

Results: The result then showed that the knowledge level of the mothers about the general knowledge of medicine was at $61 \%$ for those categorized into good knowledge and 39\% for those categorized into medium-level knowledge. Meanwhile, in terms of knowledge level of mother about complaint and diseases treatable using self-medication was at $90 \%$ for those categorized into good knowledge and $10 \%$ for those categorized at medium-level knowledge.

Conclusion: The factors determining the knowledge level of mothers included age, educational level and income. On the other hand, the factor that mostly determined the knowledge level of mother was educational level.
\end{abstract}

Keywords: self-medication, knowledge level, Yogyakarta

\section{Intisari}

Latar belakang: Swamedikasi adalah upaya yang paling banyak dilakukan masyarakat untuk mengatasi gejala penyakit sebelum mencari pertolongan dari tenaga kesehatan Pengetahuan tentang obat dan keluhan penyakit berdampak pada penggunaan obat. Keterbatasan pengetahuan para ibu akan obat dan cara penggunaannya dalam swamedikasi dapat menjadi sumber terjadinya kesalahan pengobatan (medication error) pada diri sendiri dan anggota keluarganya. Pengetahuan yang dibutuhkan untuk melakukan swamedikasi dengan benar adalah mengetahui bahan aktif, indikasi, kontraindikasi, dosis, dan efek samping pengobatan.

Tujuan: Tujuan penelitian untuk mengetahui gambaran pelaksanaan swamedikasi,mengetahui gambaran tingkat pengetahuan para ibu tentang swamedikasi dan mengetahui faktor- faktor yang mempengaruhi tingkat pengetahuan para ibu.

Metode: Penelitian menggunakan kuesioner yang disusun berdasarakan Pedoman Penggunaan Obat Bebas dan Obat Bebas Tebatas. Pembagian golongan tingkat pengetahuan para ibu berdasarkan skor 


\begin{abstract}
akhir kuesioner.
Hasil: Tingkat pengetahuan para ibu tentang informasi umum obat, sebanyak 61\% ibu tergolong pengetahuan baik dan 39\% ibu tergolong pengetahuan sedang. Tingkat pengetahuan para ibu tentang keluhan dan penyakit yang dapat diatasi dengan swamedikasi, sebanyak $90 \%$ ibu tergolong pengetahuan baik dan $10 \%$ ibu tergolong pengetahuan sedang.

Kesimpulan: Faktor yang mempengaruhi tingkat pengetahuan ibu antara lain usia, tingkat pendidikan dan tingkat penghasilan. Sedangkan faktor yang paling mempengaruhi tingkat pengetahuan para ibu adalah tingkat pendidikan.
\end{abstract}

Kata kunci : Swamedikasi, tingkat pengetahuan, para ibu, Cangkringan

\title{
1. Pendahuluan
}

Pengobatan sendiri, atau yang disebut dengan swamedikasi, merupakan upaya yang paling banyak dilakukan masyarakat untuk mengatasi gejala penyakit sebelum mencari pertolongan dari tenaga kesehatan (Kemenkes, 2008). Hasil Susenas pada tahun 2009 juga mencatat bahwa 66\% orang sakit di Indonesia melakukan swamedikasi untuk mengatasi penyakitnya (Kartajaya, 2011). Dari data World Health Organization (1998), di banyak negara sampai 80\% orang yang sakit mencoba untuk melakukan pengobatan sendiri oleh penderita. Sedangkan data di Indonesia menunjukkan bahwa sekitar 60\% masyarakat melakukan swamedikasi dengan obat modern sebagai tindakan pertama bila sakit (Kemenkes, 2009).

Kesehatan didefinisikan sebagai keadaan sejahtera dari badan, jiwa, dan sosial yang memungkinkan setiap orang hidup produktif baik secara sosial dan ekonomi (Kemenkes, 2009). Dalam upaya pemeliharaan kesehatan, pengobatan sendiri merupakan upaya pertama dan yang terbanyak dilakukan masyarakat untuk mengatasi keluhan kesehatannya sehingga peranannya tidak dapat diabaikan begitu saja. Keterbatasan pengetahuan masyarakat tentang obat dan penggunaannya merupakan penyebab terjadinya kesalahan pengobatan dalam swamedikasi (Suryawati, 1997). Keterbatasan tersebut dapat menyebabkan rentannya masyarakat terhadap informasi komersial obat, sehingga memungkinkan terjadinya pengobatan yang tidak rasional jika tidak diimbangi dengan pemberian informasi yang benar (Kemenkes, 2013). Untuk itu penelitian ini akan mtenganalisis tingkat pengetahuan yang dimiliki para ibu tentang swamedikasi pada anak.

Ibu dapat diasumsikan sebagai "dokter keluarga" yang bertanggung jawab terhadap kesehatan anak-anaknya. Saat ini, dengan makin berkembangnya teknologi sebagai sumber informasi khususnya iklan tentang produk kesehatan (obat) menjadikan para ibu mudah mendapat pengetahuan tentang obat bebas. Penulis mendapati tidak sedikit para ibu membeli sendiri obat bebas di Apotek tanpa resep dokter untuk mengatasi gejala penyakit pada anaknya. Dengan begitu, sangat penting untuk mengetahui tingkat pengetahuan para ibu tentang swamedikasi untuk 
mencegah terjadinya self medication error. Keterbatasan pengetahuan tentang pilihan penggunaan obat dan pemilihan dosis obat pada anak dapat berdampak terjadinya medication error. Dalam keluarga, ibu adalah sosok yang bertanggung jawab terhadap kesehatan anak-anaknya. Informasi yang benar, dapat mendukung keberhasilan swamedikasi yang dilakukan para ibu pada anak.

Kecamatan Cangkringan merupakan salah satu kecamatan yang berdampak langsung ketika erupsi gunung Merapi. Praktek swamedikasi di daerah bencana umumnya meningkat (Purwanti, et al., 2004). Selain daerah yang rawan bencana, kecamatan Cangkringan juga merupakan kecamatan yang terletak di daerah pedesaan. Bagi masyarakat di daerah terpencil, swamedikasi akan menghemat banyak waktu yang diperlukan untuk ke kota mengunjungi dokter (Purwanti, 2008). Tingkat pengetahuan yang baik akan berdampak pada keberhasilan terapi dan menurunkan kesalahan pengobatan yang banyak terjadi pada praktek swamedikasi. Oleh karena itu, penting mengetahui tingkat pengetahuan yang dimiliki para ibu tentang swamedikasi yang tinggal di Kecamatan Cangkringan.

\section{Metodologi penelitian}

\subsection{Populasi dan sampel}

Populasi ibu yang memiliki anak $\leq 12$ sebesar 406 orang. Dengan menggunakan rumus Slovin (Sastroasmoro, 2008). Jumlah sampel minimum sebesar 202 orang, dan ditambah 30 orang untuk mengukur validitas dan reabilitas kuesioner. Teknik sampling dilakukan dengan metode non probabilitas.

\subsection{Tempat dan waktu penelitian}

Penelitian dilakukan pada bulan Mei sampai Juni 2014 dari rumah ke rumah di Kecamatan Cangkringan, Sleman Yogyakarta.

\subsection{Kriteria inklusi dan eksklusi}

Kriteria inklusi dalam penelitian ini adalah para ibu yang memiliki anak $\leq 12$ tahun dan para ibu yang melakukan swamedikasi menggunakan obat bebas dan obat bebas terbatas untuk anaknya. Kriteria eksklusi pada penelitian ini adalah para ibu yang tidak bersedia bekerja sama dalam penelitian. 


\subsection{Alat dan bahan}

Alat yang digunakan dalam penelitian ini adalah kuesioner yang dibuat sendiri berdasarkan Pedoman Penggunaan Obat Bebas dan Obat Bebas Terbatas yang dikeluarkan oleh Ditjen Bina Kefarmasian Dan Alat Kesehatan Departemen Kesehatan 2006.

\subsection{Pengolahan data dan analisis data}

\section{a. Penilaian kuesioner}

Data yang telah didapatkan kemudian dilakukan pemeriksaan atas kelengkapan pengisian kuesioner, kejelasan makna jawaban dan perbaikan isian kuesioner tersebut. Uji validitas digunakan untuk mengukur sah atau valid tidaknya suatu kuesioner. Kuesioner dikatakan valid jika pertanyaan pada kuesioner tersebut mampu mengungkapkan sesuatu yang akan diukur oleh kuesioner tersebut. Uji Reabilitas adalah indeks yang menunjukkan sejauh mana suatu alat pengukuran dapat dipercaya atau dapat diandalkan. Jika nilai Cronbach's Alpha lebih besar dari 0,600, maka kuesioner dapat dinyatakan realibel (Gaspersz, 1991).

b. Interpretasi data

Gambaran pelaksanaan swamedikasi didapat dari tabulasi jawaaban dari kuesioner yang dibagikan.

Gambaran Pengetahuan :

1. Tingkat pengetahuan tentang swamedikasi
a) Baik, apabila skor responden $\geq 80$
b) Sedang, apabila skor responden 60-79
c) Buruk, apabila skor responden $<60$

2. Tingkat kejadian swamedikasi (dalam 3 bulan). Dibagi dalam 4 kategori kejadian :

a. Sangat sering, bila tingkat kejadian $>75 \%$ atau $>30$ kali dalam 3 bulan

b. Sering, bila tingkat kejadian $50-75 \%$ atau $15-30$ kali dalam 3 bulan

c. Jarang, bila tingkat kejadian 20-49\% atau 6-14 kali dalam 3 bulan

d. Sangat jarang, bila tingkat kejadian $<20 \%$ atau kurang dari 6 kali dalam 3 bulan. 
3. Faktor yang mempengaruhi tingkat pengetahuan para ibu. Beberapa faktor yang mempengarui tingkat pengetahuan seseorang di dapat dari kajian literature. Diantaranya umur, tingkat pendidikan, dan tingkat penghasilan. Data dianalisa dengan analisa univariat dan regresi linear menggunakan software SPSS versi 17 dan hasil disajikan dalam bentuk tabel frekuensi dan persentase.

\section{Hasil dan pembahasan}

\subsection{Penyusunan kuesioner}

Kuesioner yang dibuat terdiri dari tiga bagian, bagian pertama memuat gambaran pelaksanaan swamedikasi, bagian kedua tentang informasi umum obat dan bagian ketiga tentang keluhan dan penyakit yang dapat diatasi dengan swamedikasi. Masing- masing bagian memuat sepuluh butir soal. Kuesioner bagian pertama terdiri dari sepuluh butir soal dengan lima pilihan jawaban. Soal pada kuesioner bagian pertama tidak dijadikan sebagai alat untuk mengukur tingkat pengetahuan para ibu melainkan dijadikan sebagai informasi mengenai gambaran pelaksanaan swamedikasi yang dilakukan para ibu di Kecamatan Cangkringan. Sedangkan kuesioner bagian kedua dan ketiga masing-masing terdiri dari sepuluh butir soal dengan dua pilihan jawaban. Kuesioner bagian kedua dan ketiga digunakan untuk mengukur tingkat pengetahuan para ibu, pilihan jawaban yang salah diberi skor nol sedangkan jawaban benar diberi skor sepuluh.

Ketiga puluh butir soal kemudian diuji validitas dan reabilitasnya. Uji validitas dan reabilitas dilakukan hanya sekali dan langsung mendapatkan hasil yang baik. Hasil uji validitas ketiga puluh butir soal menunjukkan nilai $\mathrm{p}<\alpha(0,05)$ untuk masing-masing soal dan dinyatakan valid. Hasil uji reabilitas yang dilakukan pada tiap bagian kuesioner menunjukkan nilai Cronbach's alpha $>0.600$ dan dinyatakan realibel.

\subsection{Gambaran pelaksanaan swamedikasi yang dilakukan para ibu di Kecamatan Cangkringan}

Berdasarkan hasil, sebanyak 61\% alasan para ibu di Kecamatan Cangkringan melakukan swamedikasi adalah untuk menghemat biaya. Sebanyak 28\% para ibu beralasan melakukan swamedikasi untuk menghemat waktu. Sebanyak 6\% para ibu melakukan swamedikasi dengan alasan keberhasilan engalaman sebelumnya. Sebanyak 5\% para ibu melakukan swamedikasi dengan alasan rekomendasi tenaga kesehatan. 


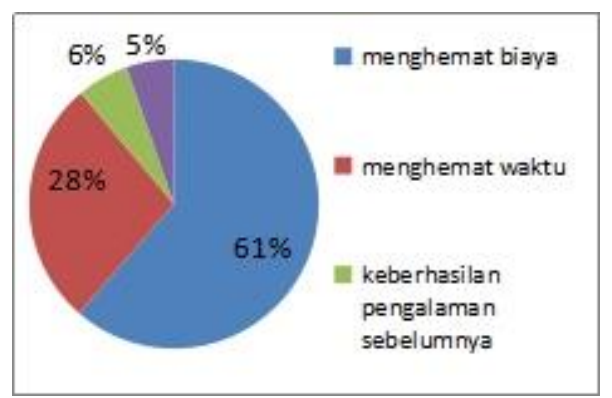

Gambar 1. Alasan para ibu melakukan swamedikasi

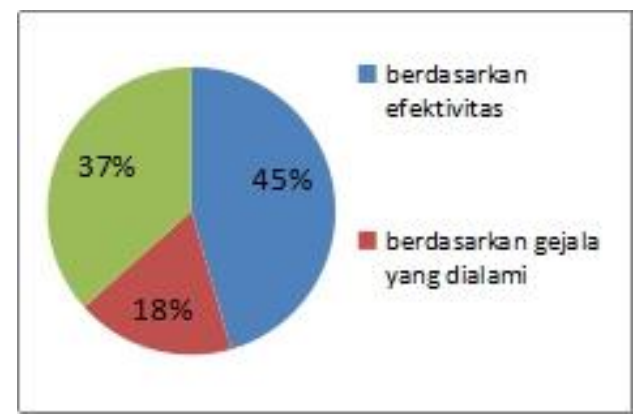

Gambar 2. Pertimbangan para ibu dalam memilih obat

Berdasarkan hasil, paling banyak para ibu memilih obat dengan pertimbangan efektivitas dari obat yang akan dibeli. Para ibu yang memilih obat berdasarkan efektivitas sebanyak 45\%. Efektif tidaknya suatu obat yang akan dibeli dilatarbelakangi oleh pengalaman sebelumnya dengan menggunakan obat yang sama atau rekomendasi tenaga kesehatan maupun kerabat atau tetangga rumah. Sebanyak 37\% para ibu memilih obat dengan pertimbangan berdasarkan gejala penyakit yang dialami. Sebanyak 18\% para ibu memilih obat dengan pertimbangan berdasarkan pengalaman baik itu diri sendiri, teman ataupun tetangga.

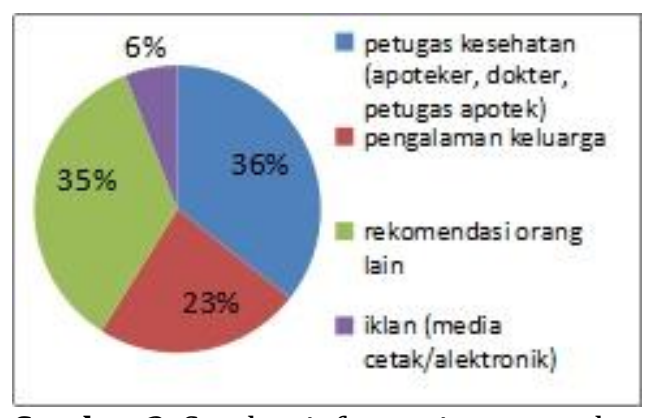

Gambar 3. Sumber informasi tentang obat

Para ibu umumnya sangat mengetahui informasi obat-obat yang sebelumnya pernah digunakan dan berhasil mengobati gejala dan penyakit. Dari hasil, sebanyak 36\% para ibu memperoleh informasi tentang obat dari petugas kesehatan Petugas kesehatan yang biasanya ditemui yaitu bidan, petugas apotek dan dokter. Informasi yang berasal dari petugas kesehatan 
umumnya memiliki tingkat keberhasilan terapi yang tinggi dibanding dengan sumber informasi tersier lainnya. Sebanyak 35\% para ibu mendapatkan informasi tentang obat dari rekomendasi orang lain. Sebanyak 23\% para ibu memperoleh informasi tentang obat dari pengalaman keluarga. Sebanyak 6\% para ibu memperoleh informasi tentang obat dari iklan baik itu media cetak maupun elektronik.

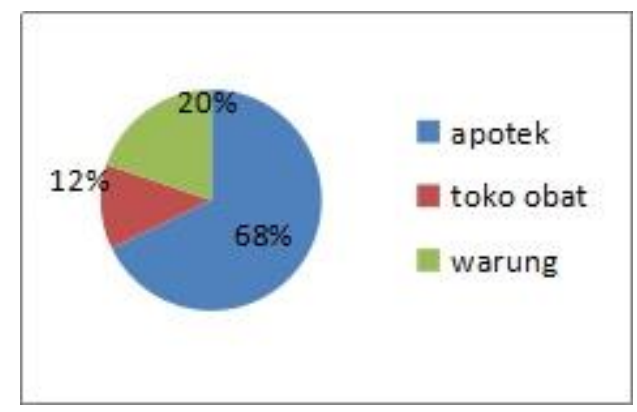

Gambar 4. Tempat memperoleh obat bebas dan atau obat bebas

Obat bebas dan obat bebas terbatas dapat diperoleh secara bebas di tempat- tempat penjualan selain apotek. Dari hasil, sebanyak 68\% para ibu membeli obat di apotek. Sebanyak 20\% para ibu memilih warung sebagai tempat untuk membeli obat. Sebanyak 12\% para ibu membeli obat di toko obat. Berdasarkan hasil, sebanyak 54\% para ibu biasa membeli obat pereda nyeri seperti asam mefenamat dan ibuprofen. Obat analgesic-antipiretik yang paling banyak dibeli adalah paracetamol.

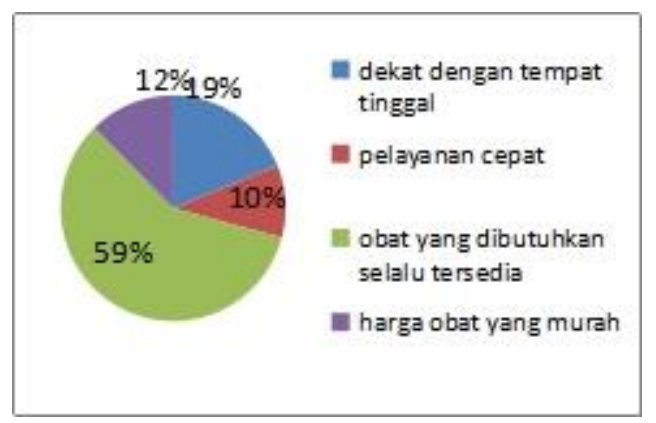

Gambar 5. Alasan para ibu membeli obat di apotek, toko obat dan warung.

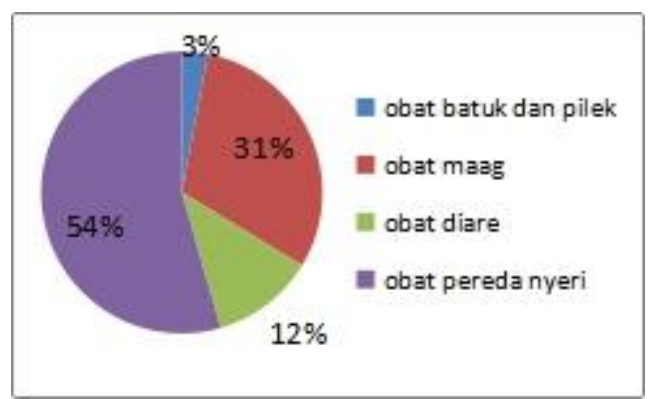

Gambar 6. Jenis obat yang biasa dibeli 
Sebanyak 31\% para ibu membeli obat maag. Kombinasi alumunium hidroksida dan magnesium hidroksida merupakan obat yang paling banyak dibeli. Sebanyak 12\% para ibu biasa melakukan swamedikasi terhadap flu dan batuk. Dan sangat sedikit para ibu membeli obat diare, yaitu sebanyak 3\%. Obat diare yang paling banyak dibeli adalah attapulgit dan kaolin-pektin. Dari hasil, biaya yang harus dikeluarkan para ibu paling banyak sebesar lima ribu sampai sepuluh ribu rupiah. Sebanyak 18\% mengeluarkan biaya mulai dari sepuluh ribu rupiah sampai tiga puluh ribu rupiah. Sebanyak 16\% mengeluarkan biaya kurang dari lima ribu rupiah dan sisanya sebanyak 8\% memperoleh obat secara gratis, yang diperoleh dari teman dan tetangga.

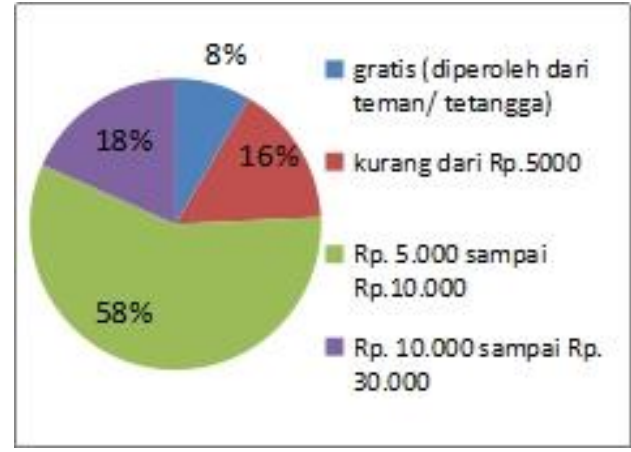

Gambar 7. Biaya yang harus dikeluarkan untuk membeli obat

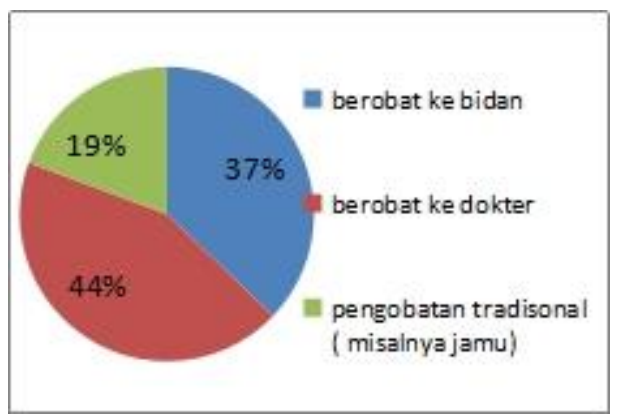

Gambar 8. Tindakan para ibu jika pengobatan gagal dengan swamedikasi.

Berdasarkan hasil, hal yang paling banyak dilakukan para ibu ketika penyakit tidak juga sembuh adalah berobat ke dokter. Sebanyak 44\% para ibu memilih dokter sebagai rujukan pertama bila penyakit dan gejala penyakit tidak juga sembuh. Keberadaan dokter di sarana pelayanan kesehatan seperti puskesmas tidak selalu ada, hanya pada hari- hari tertentu saja dokter bertugas di tempat tersebut. Selain dokter, sebanyak 37\% para ibu memilih berobat ke bidan desa. Sebanyak 19\% para ibu memutuskan menggunakan pengobatan tradisional seperti jamu bila dengan swamedikasi gejala penyakit maupun penyakit tidak kunjung sembuh. Para ibu yang memutuskan berobat ke dokter memiliki beberapa alasan. Paling banyak para ibu memutuskan pergi ke dokter jika obat yang dibeli sudah habis tetapi tidak kunjung sembuh. 


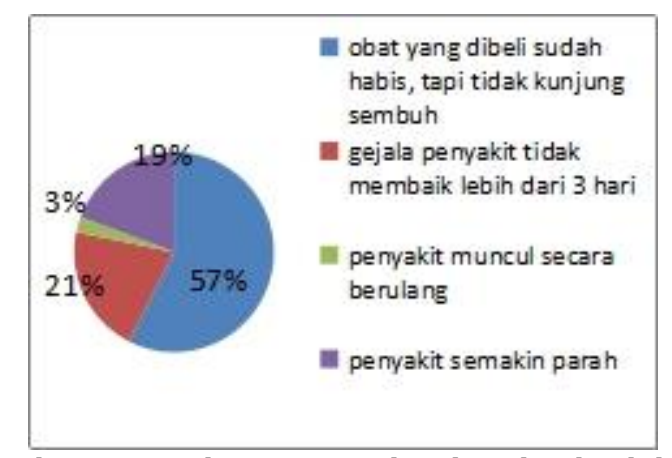

Gambar 9. Alasan para ibu memutuskan berobat ke dokter

\subsection{Gambaran tingkat pengetahuan}

a. Tingkat pengetahuan tentang informasi umum obat

Para ibu yang memutuskan berobat ke dokter memiliki beberapa alasan. Paling banyak para ibu memutuskan pergi ke dokter jika obat yang dibeli sudah habis tetapi tidak kunjung sembuh.

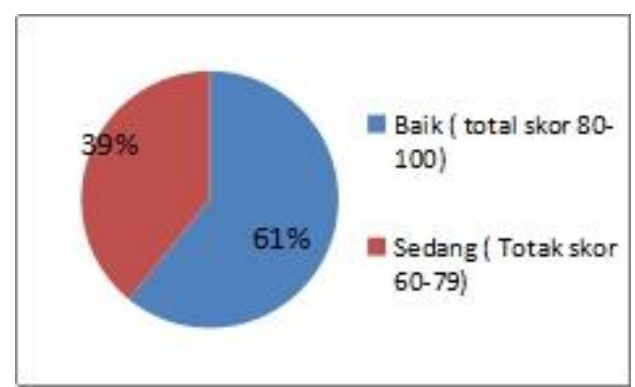

Gambar 10. Tingkat pengetahuan tentang informasi umum obat

b. Tingkat pengetahuan tentang keluhan dan penyakit yang dapat diatasi dengan swamedikasi

Berdasarkan total skor jawaban responden pada kesepuluh soal dibagian ketiga kuesioner tentang keluhan dan penyakit yang dapat diatasi dengan swamedikasi didapat sebanyak 90\% termasuk kategori berpengetahuan baik sedangkan 10\% termasuk dalam kategori berpengetahuan sedang. Tidak ditemukan ibu yang masuk dalam kategori berpengetahuan buruk.

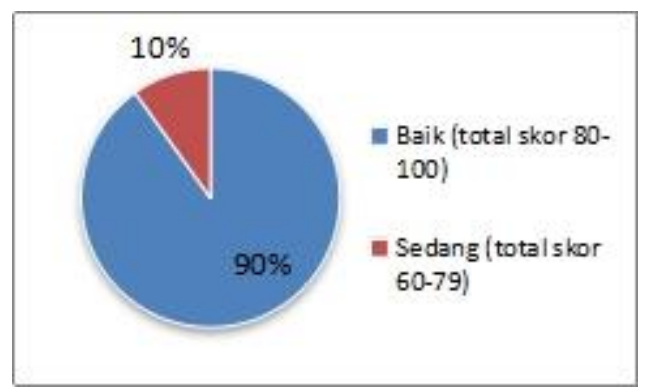

Gambar 11. Tingkat pengetahuan tentang keluhan dan penyakit yang dapat diatasi dengan swamedikasi 
c. Tingkat kejadian swamedikasi dalam tiga bulan terakhir.

Berdasarkan hasil, tingkat kejadian swamedikasi yang dilakukan para ibu di kecamatan cangkringan sangat beragam. Pada penelitian ini, tingkat kejadian yang diukur yakni dalam 3 bulan terkahir. Sebanyak 87\% responden masuk pada kategori sangat jarang melakukan swamedikasi, sebanyak 10\% termasuk kategori jarang melakukan swamedikasi, dan 3\% responden masuk dalam kategori sering melakukan swamedikasi.

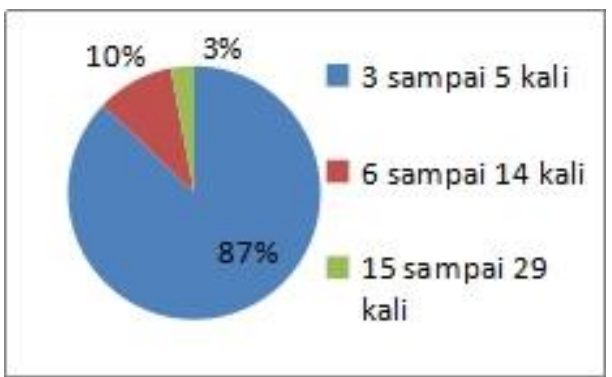

Gambar 12. Distribusi tingkat kejadian swamedikasi

\subsection{Faktor yang mempengaruhi tingkat pengetahuan para ibu}

a. Usia

Berdasarkan hasil, diperoleh usia responden yang berada diatas 30 tahun sebanyak 41\% dan sebanyak 59\% responden berada pada kisaran umur dibawah 30tahun. Para ibu yang berada di kisaran umur kurang dari 30 tahun termasuk dalam kategori ibu muda, dengan jumlah anak 1-2 orang.

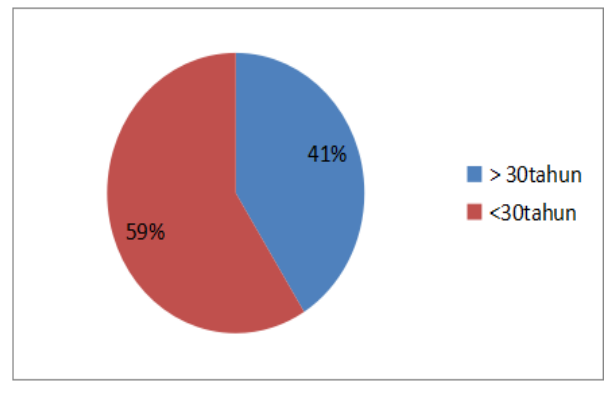

Gambar 13. Distribusi usia para ibu

Pada kuesioner bagian kedua tentang Informasi Umum Obat, untuk kelompok para ibu usia diatas 30 tahun ada sebanyak 30\% yang memiliki pengetahuan baik dan 12\% yang berpengetahuan sedang. Sedangkan kelompok para ibu kategori usia kurang dari 30 tahun, ada sebanyak 33\% yang masuk dalam kategori pengetahuan baik dan 26\% yang memiliki tingkat pengetahuan sedang. 


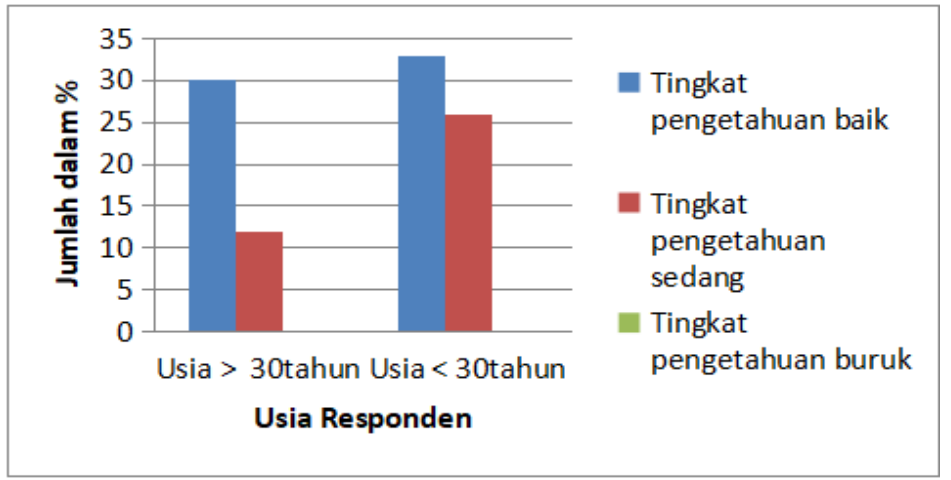

Gambar 14. Distribusi tingkat pengetahuan para ibu tentang informasi umum obat berdasarkan usia.

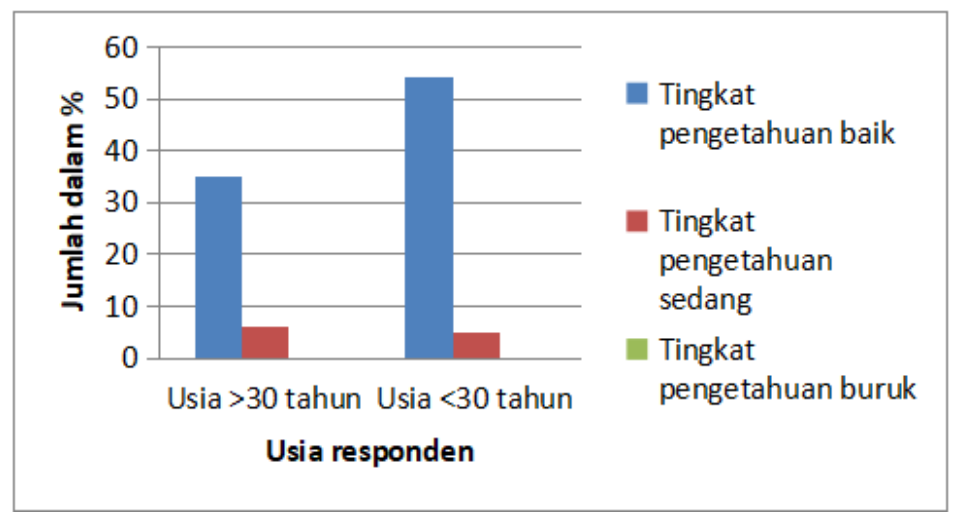

Gambar 15. Distribusi tingkat pengetahuan para ibu tentang keluhan dan penyakit yang dapat diatasi dengan swamedikasi berdasarkan usia

Pada kuesioner bagian ketiga tentang Keluhan dan Penyakit yang dapat diatasi dengan Swamedikasi, untuk kelompok para ibu usia diatas 30 tahun ada sebanyak 35\% yang memiliki pengetahuan baik dan 6\% yang berpengetahuan sedang. Sedangkan kelompok para ibu kategori usia kurang dari 30 tahun, ada sebanyak 54\% yang masuk dalam kategori pengetahuan baik dan 5\% yang memiliki tingkat pengetahuan sedang. Hasil ini sangat bertolak belakang dengan teori. Umur merupakan faktor internal individu yang dihitung sejak lahir yang menentukan faktor predisposisi untuk terjadinya perubahan pengetahuan dan perilaku. Faktor umur biasanya dikaitkan dengan kematangan fisik dan psikis seseorang (Videbeck, 2008).

b. Tingkat pendidikan

Berdasarkan hasil, paling banyak para ibu menempuh tingkat pendidikan akhir tamat SLTA yakni sebanyak 51\%, disusul para ibu dengan tingkat pendidikan akhir tamat SLTP sebesar 29\%. 
Para ibu dengan tingkat pendidikan akhir tamat perguruan tinggi sebanyak 12\%, sedangkan sebanyak 8\% ibu menamatkan pendidikan pada tingkat sekolah dasar.

Pada kuesioner bagian kedua tentang Informasi Umum Obat, untuk kelompok para ibu yang menamatkan pendidikan di bangku SD yang memiliki pengetahuan baik sebanyak 2\% dan 6\% yang berpengetahuan sedang. Kelompok para ibu yang menamatkan pendidikan pada jenjang SLTP ada sebanyak 9\% yang masuk dalam kategori pengetahuan baik dan 20\% yang memiliki tingkat pengetahuan sedang. Kelompok para ibu yang menamatkan pendidikan pada jenjang SLTA, ada sebanyak 30\% berpengetahuan baik dan 21\% berpengetahuan sedang. Kelompok ibu yang menamatkan pendidikan di jenjang Perguruan Tinggi (PT), seluruhnya berpengetahuan baik yakni sebanyak $12 \%$.

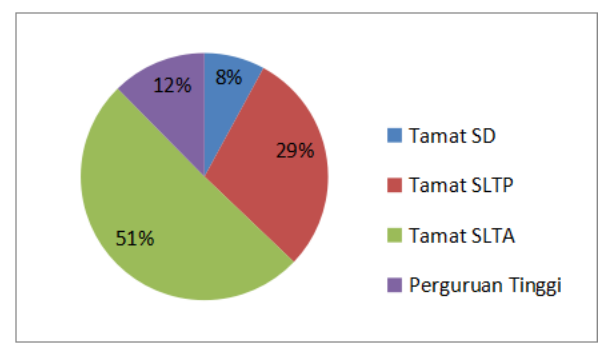

Gambar 16. Distribusi tingkat pendidikan para ibu

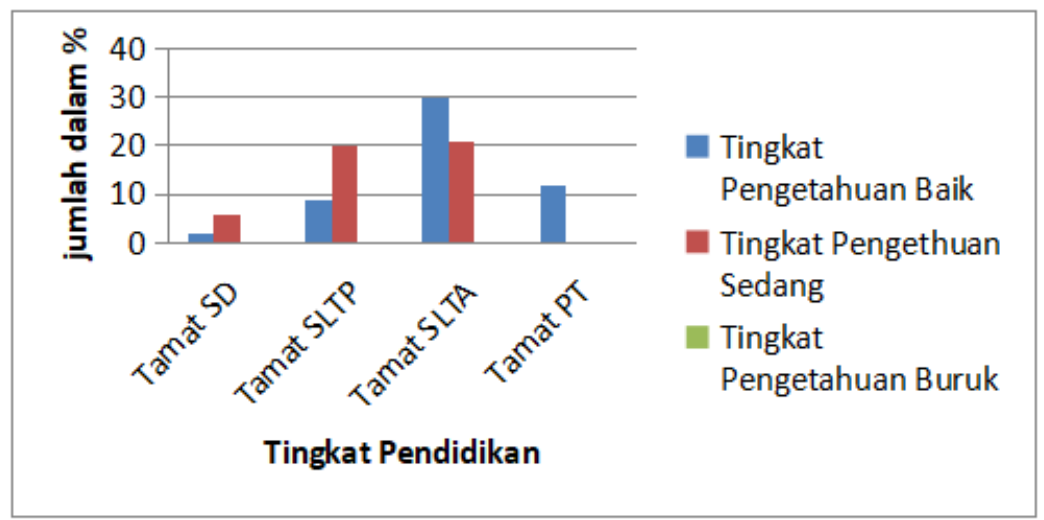

Gambar 17. Distribusi tingkat pengetahuan para ibu tentang informasi umum obat berdasarkan tingkat pendidikan

Pada kuesioner bagian ketiga tentang Keluhan dan Penyakit yang dapat diatasi dengan Swamedikasi, untuk kelompok para ibu yang menamatkan pendidikan di bangku SD ada sebanyak 3\% yang masuk kategori berpengetahuan baik dan 5\% yang berpengetahuan sedang. Kelompok para ibu yang menamatkan pendidikan di bangku SLTP, ada sebanyak 19\% berpengetahuan baik dan $10 \%$ pengetahuan sedang. Kelompok para ibu yang menamatkan pendidikan pada jenjang 
SLTA ada sebanyak 41\% yang memiliki tingkat pengetahuan baik dan $10 \%$ masuk kategori berpengetahuan sedang. Sedangkan kelompok ibu yang menamatkan pendidikan jenjang Perguruan Tinggi, seluruhnya berpengetahuan baik yakni sebesar 12\%. Berdasarkan hasil penelitian ini dapat disimpulkan bahwa semakin tinggi tingkat pendidikan seseorang, semakin tinggi pengetahuannya serta semakin berhati-hati dalam penggunaan obat dalam pengobatan sendiri.

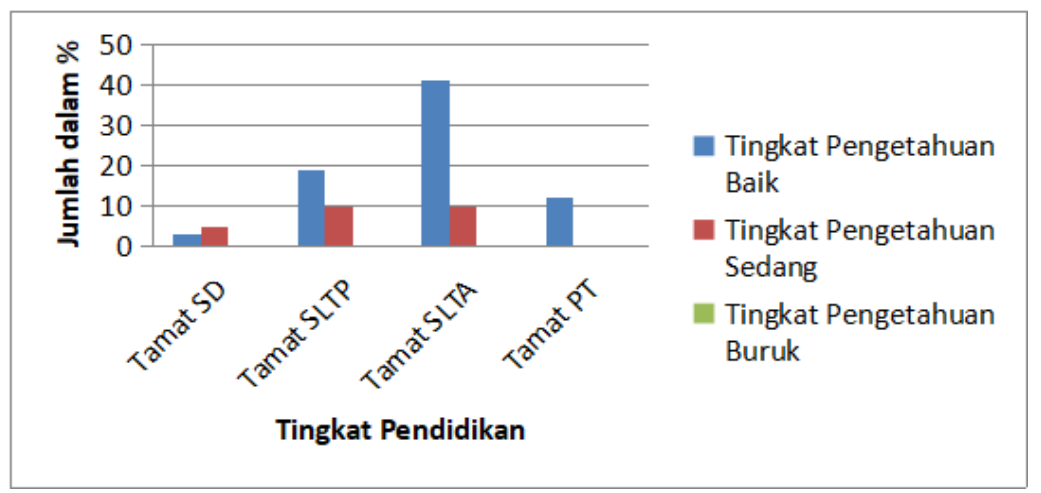

Gambar 18. Distribusi tingkat pengetahuan para ibu tentang keluhan dan penyakit yang dapat diatasi dengan swamedikasi berdasarkan tingkat pendidikan

c. Tingkat pendapatan

Berdasarkan hasil, didapat sebanyak 81\% para ibu berpenghasilan kurang dari Upah Minimum Rakyat (UMR) Kabupaten Sleman, yakni sebesar satu juta seratus dua puluh tujuh rupiah. Sisanya sebanyak 19\% berpenghasilan lebih dari satu juta seratus dua puluh tujuh rupiah. Pada kuesioner bagian kedua tentang Informasi Umum Obat, untuk kelompok para ibu yang berepenghasilan kurang dari UMR ada sebanyak 58\% berpengetahuan baik dan 23\% yang berpengetahuan sedang. Kelompok para ibu yang berpenghasilan lebih dari UMR ada sebanyak $13 \%$ berpengetahuan baik dan $6 \%$ berpengetahuan sedang.

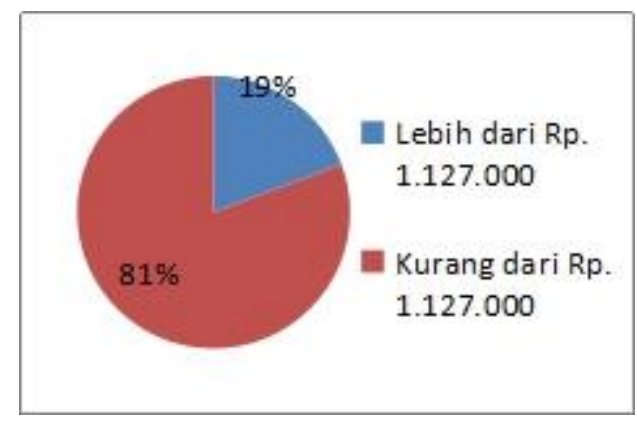

Gambar 19. Distribusi tingkat pendapatan per bulan 


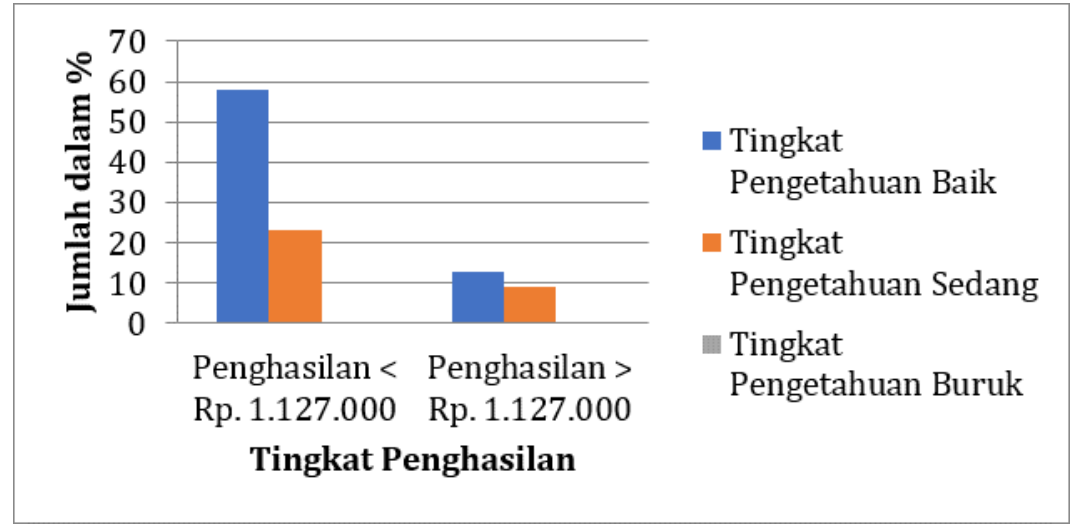

Gambar 20. Distribusi tingkat pegetahuan para ibu tentang informasi umum obat berdasarkan tingkat penghasilan

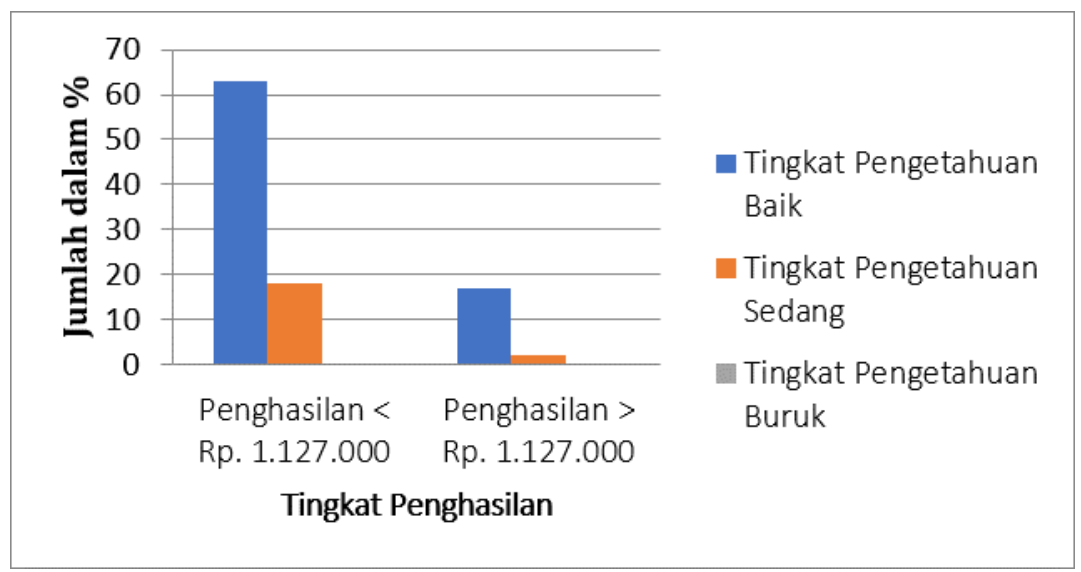

Gambar 21. Distribusi tingkat pengetahuan para ibu tentang keluhan dan penyakit yang dapat diatasi dengan swamedikasi berdasarkan tingkat penghasilan

Pada kuesioner bagian ketiga tentang Keluhan dan Penyakit yang dapat diatasi dengan swamedikasi, untuk kelompok para ibu yang berepenghasilan kurang dari UMR ada sebanyak 63\% berpengetahuan baik dan 18\% yang berpengetahuan sedang. Kelompok para ibu yang berpenghasilan lebih dari UMR ada sebanyak 17\% berpengetahuan baik dan 2\% berpengetahuan sedang. Berdasarkan hasil, diketahui bahwa yang berpendapatan lebih tinggi umunya memiliki pengetahuan lebih baik, ini bertolak belakang dengan teori. Pendapatan tidak berpengaruh langsung terhadap pengetahuan seseorang. Namun bila seseorang berpendapatan cukup besar maka dia akan mampu untuk menyediakan atau membeli fasilitas - fasilitas sumber informasi. Dari data, kemudian dilakukan analisis regresi logistik untuk mengetahui adakah hubungan antara variable independent dan variable dependent secara serentak (Sugiyono, 2007). 
Berdasarkan hasil analisis untuk tingkat pengetahuan para ibu tentang informasi umum obat, menggunakan 202 sampel dengan nilai Cox and Snell sebesar 0,501 yang berarti 50,1\% variasi dari tingkat pengetahuan tentang informasi umum obat dapat dijelaskan oleh variable independent yang digunakan. Nilai Naqelkerke sebesar 0,765 yang berarti 76,5\% variasi dari tingkat pengetahuan para ibu tentang informasi umum obat dapat dijelaskan oleh variabel independent yang digunakan. Nilai overall percentage sebesar 81,7 yang bermakna persentasi variable yang dapat diprediksi sebesar 81,7\%. Dari hasil, tingkat pendidikan memiliki nilai sig. < 0,05 yang berarti berpengaruh signifikan. Hasil Odds-ratio yang paling besar pada variable tingkat pendidikan sebesar 4,894. Dari data dapat disimpulkan bahwa tingkat pendidikan berpengaruh signifikan terhadap tingkat pengetahuan para ibu tentang informasi umum obat dengan peluang kejadian 4 kali dibanding variable lainnya.

Hasil analisis untuk tingkat pengetahuan para ibu tentang keluhan dan penyakit yang dapat diatasi dengan swamedikasi, menggunakan 202 sampel menunjukkan nilai Cox and Snell sebesar 0,441 yang berarti 44,1\% variasi dari tingkat pengetahuan tentang keluhan dan penyakit yang dapat diatasi dengan swamedikasi dapat dijelaskan oleh variabel independent yang digunakan. Diperoleh pula nilai Naqelkerke sebesar 0,711 yang berarti 71,1\% variasi dari tingkat pengetahuan para ibu tentang informasi umum obat dapat dijelaskan oleh variabel independent yang digunakan. Nilai overall percentage sebesar 89,1 yang bermakna persentasi variable yang dapat diprediksi sebesar 89,1\%. Hasil, tingkat pendidikan memiliki nilai sig. < 0,05 yang berarti berpengaruh signifikan. Hasil Odds-ratio yang paling besar pada variable tingkat pendidikan sebesar 6,027. Berdasarkan data dapat disimpulkan bahwa tingkat pendidikan berpengaruh signifikan terhadap tingkat pengetahuan para ibu tentang keluhan dan penyakit yang dapat diatasi dengan swamedikasi dengan peluang kejadian 6 kali dibanding variable lainnya.

\section{Kesimpulan}

Gambaran pelaksanaan swamedikasi yang dilakukan para ibu di kecamatan cangkringan : Paling banyak alasan para ibu melakukan swamedikasi adalah untuk menghemat biaya, pertimbangan para ibu dalam memilih obat adalah berdasarkan efektivitas, sumber informasi mengenai obat paling banyak diperoleh dari petugas kesehatan, para ibu banyak memperoleh obat di apotek, alasan terbanyak para ibu membeli obat di apotek adalah karena obat yang dibutuhkan selalu tersedia, jenis obat yang paling banyak dibeli adalah obat penghilang nyeri, paling banyak

para ibu mengeluarkan biaya sebesar Rp. 5.000- Rp.10.000, para ibu akan berobat ke dokter bila 
keluhan dan penyakit tidak juga sembuh dengan swamedikasi, alasan terbanyak para ibu memutuskan berobat ke dokter karena obat yang dibeli sudah dihabiskan tetapi tidak kunjung sembuh. Tingkat pengetahuan para ibu tentang informasi umum obat, sebanyak $61 \%$ ibu tergolong pengetahuan baik dan 39\% ibu tergolong pengetahuan sedang. Tingkat pengetahuan para ibu tentang keluhan dan penyakit yang dapat diatasi dengan swamedikasi, sebanyak 90\% ibu tergolong pengetahuan baik dan $10 \%$ ibu tergolong pengetahuan sedang. Faktor yang mempengaruhi tingkat pengetahuan ibu antara lain usia, tingkat pendidikan dan tingkat penghasilan. Factor yang paling mempengaruhi tingkat pengetahuan para ibu adalah tingkat pendidikan. Perlu penelitian tambahan menggali lebih banyak informasi tentang pengobatan sendiri (selfmedication), dan kemungkinan-kemungkinan ada faktor lain yang lebih berpengaruh terhadap tingkat pengetahuan para ibu.

\section{Daftar pustaka}

Gaspersz, V. 1991. Teknik Penarikan Contoh untuk Penelitian Survei. Bandung: Tarsito.

Kartajaya, H. 2008. editors. Self - Medication, Who Benefits and Who is at Loss. Jakarta : MarkPlus Insight Press. Hlm 3

Kemenkes RI. 2008. Materi Pelatihan Peningkatan Pengetahuan dan Keterampilan Memilih Obat bagi Tenaga Kesehatan. Jakarta : Kementrian Kesehatan RI.

Kemenkes RI. 2009. Tentang Pelayanan Kefarmasian, Jakarta : Direktorat Jendral Pelayanan Kefarmasian dan Alat Kesehatan Departemen Kesehatan RI.

Kemenkes RI. 2009. Undang-Undang Republik Indonesia Nomor 36 Tahun 2009 Tentang Kesehatan. Jakarta : Kementrian Kesehatan RI.

Kemenkes RI. 2013. Riset Kesehatan Dasar Tahun 2013. Jakarta : Kementrian Kesehatan RI.

Purwanti, A. Harianto dan Supardi. 2004. Gambaran Pelaksanaan Standar Pelayanan Farmasi di Apotek DKI Jakarta Tahun 2003. Jakarta : Majalah Ilmu Kefarmasian vol 1,2, hlm 102-115.

Sastroasmoro, S. 2008. Dasar-dasar Metodologi Penelitian Klinis. Jakarta : Bina Rupa Aksara.

Sugiyono. 2007. Metode Penelitian Kuantitatif Kualitatif dan R\&D. Bandung : Alfabeta.

Suryawati, S. 1997. Menuju Swamedikasi yang Rasional. Yogyakarta : Pusat Studi Farmakologi Klinik dan Kebijakan Obat Universitas Gadjah Mada.

Videbeck, S. L. 2008. Keperawatan Jiwa. Jakarta : Penerbit Buku Kedokteran EGC.

World Health Organization. 2008. The Role of The Pharmacist in Self-Care and Self-Medication. The Hague, The Netherlands: WHO. hal.1-11. 